\title{
Janusz Dyduch
}

Prof. dr hab. inż.

Uniwersytet Technologiczno-Humanistyczny w Radomiu, Wydział Transportu, Elektrotechniki i Informatyki,

Katedra Systemów Sterowania w Transporcie janusz.dyduch@uthrad.pl

\section{Jacek Paś}

Dr hab. inż.

Wojskowa Akademia Techniczna Wydział Elektroniki, Instytut Systemów Elektronicznych, Zakład Eksploatacji Systemów Elektronicznych jacek.pas@wat.edu.pl

\section{Krzysztof Jakubowski}

Por. mgr inż.

Ministerstwo Obrony Narodowej, Legionowo

k.jakubowski@ron.mil.pl

DOI: 10.35117/A_ENG_19_12_03

\section{Electronic safety systems used on a vast railway area - operational problems}

\begin{abstract}
The article presents issues related to the use of electronic security systems (ESB) on a vast railway area. These systems are operated in very different environmental conditions. Due to the fact that electrical and electronic systems coexist on the extensive railway area for various purposes - e.g. power supply systems for railway traction, rail traffic control systems (SRK), electronic security systems - fire alarm system (SSP), CCTV system (CCTV), access control system (SKD), a significant operational problem in addition to environmental changes in which the above-mentioned technical facilities are used, there is also the issue of electromagnetic compatibility. Depending on the area extent of the railway area, construction, technical configuration, way of alarming, safety classes of these systems may be different. In SSP there is another factor that affects the configuration of these systems, namely the socalled fire scenario and how to notify the State Fire Service (PSP) about an existing fire risk or damage. There are several different ESB structures - focused, distributed and mixed. The type of ESB used in a given railway facility - construction or open area is conditioned by its cubic capacity $[\mathrm{m} 3]$, terrain extent $\left[\mathrm{m}^{2}\right.$ or $\left.\mathrm{km}^{2}\right]$ and the number of supervised facilities. The use of a given type of ESB to ensure safety and fire protection in a given railway area also depends on the requirements of legal provisions for the object(s), the fire scenario that must be implemented by the system, legal requirements for the given protected area, the accepted scope of protection and the reliability and operational requirements to be met by these installations. The article presents basic issues related to ESB operation that are used in the selected railway area. The review of technical solutions of selected ESBs and the methodology of conducting the analysis for the purposes of developing, e.g. fire scenario or hazard analysis, presented in the article, will enable railway facility designers to properly develop design assumptions.
\end{abstract}

Keywords: Operation; Electronic security systems; Railway facilities 


\section{Selected requirements for electronic security systems}

Electronic security systems are a set of interacting elements that form a deliberately oriented whole to ensure physical security, violation of detection zones, including a fire in a selected building object or on a large railway area - Fig. 1. The electronic safety system can then be saved as an expression determined by the formula 1 .

$$
\mathrm{ESBM}=[\mathrm{E} ; \mathrm{W} ; \mathrm{R}]
$$

where: ESBM - ESB system matrix, E - vector of all elements, ESB components, W - vector property of individual ESB elements, R - vector of transfer relations (information flow) or connections (wired controls) and wireless, stabilization, etc.) between individual ESB elements (e.g. detector - control panel, control panel - actuator system - actuator, solenoid valve for fire extinguishing cylinder, fire dampers and shut-off dampers, fire alarm and damage transmission device to PSP, CCTV observation line - alarm notification method, attempted false access to the room - SDK - alarm triggering, patrol intervention, etc.).

Electronic security systems are systems whose purpose is to detect hazards occurring in the transport process (both for stationary and mobile facilities) $[7,11,16,19]$. These systems are increasingly used in the transport process, where they ensure security:

1. people (e.g. surveillance systems installed in airport permanent facilities, train stations, ports, etc.);

2. goods carried in permanent facilities (e.g. logistics bases, land and sea reloading terminals, etc.);

3. goods transported in mobile facilities (rail, road and sea transport - and in combination with the GPS system they can monitor the load status and route of a given means of transport).

The installation of electronic security systems, such as CCTV, SSWiN, SKD on railway areas results from the way of ensuring the level of security of the entire critical infrastructure, which includes the extensive transport area. The functional structure of the ESB, the method of notifying about the threat, the organization of the emergency call centre (ACO) depends on the investor who organizes and equips the entire integrated security system and the resulting regulations. The situation is different for SSPs which must be in a vast railway area in accordance with applicable laws and regulations in force in Poland. Pursuant to $\S 31$ of the Regulation of the Minister of the Interior and Administration of 6/7/2010 on fire protection of buildings and other building structures and areas (Journal of Laws No. 109, item 719), owner, administrator or user of extensive railway areas, about referred to in art. 5 of the Act of 24 August 1991 on fire protection, coordinates with the locally competent district (municipal) commandant of the State Fire Service how to connect the SSP signalling and alarm devices with the object of the State Fire Service or the object indicated by the commandant. Using the definition contained in the SSP Regulation, it includes a system that includes: signalling and alarm devices for automatic detection and transmission of information about the fire, fire alarm receiving devices and damage signal receiving devices - Fig. 2 [8,12,14,15,17]. 


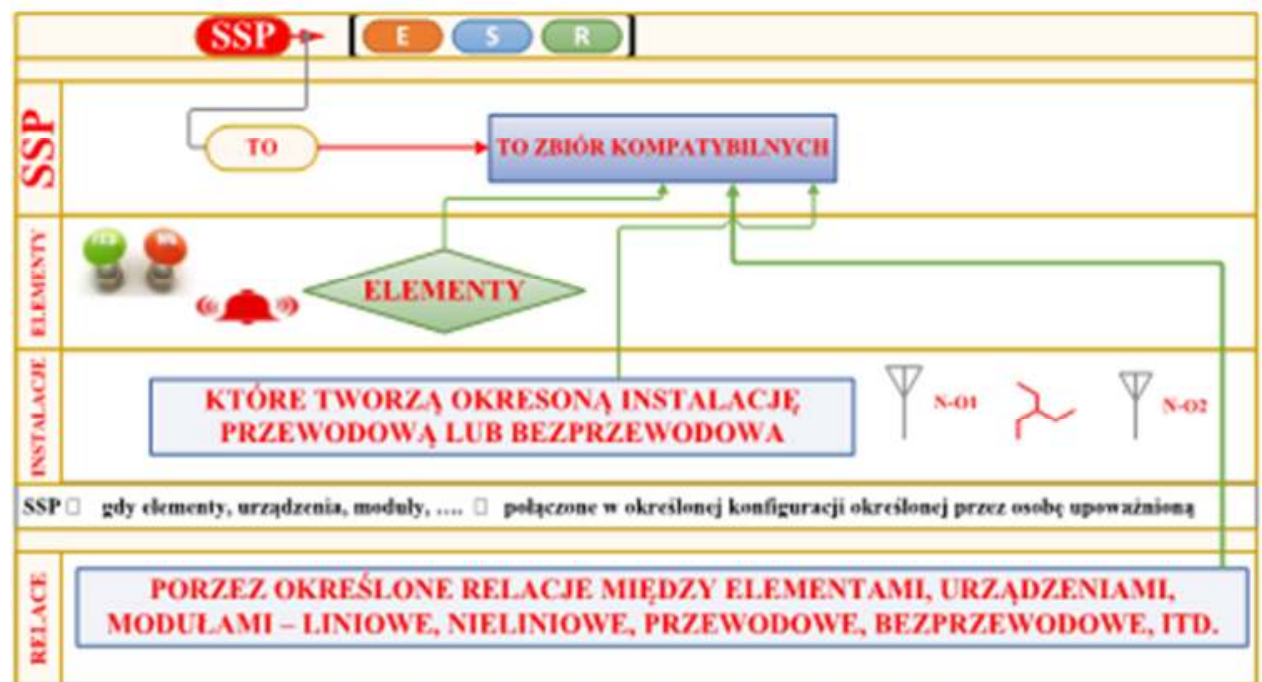

1. Electronic security system - interacting elements that form a deliberately oriented whole to ensure security in a selected building object or on a large railway area

Fire alarm signals and fault signals generated in the SSP are sent by fire monitoring. Fire monitoring involves sending, with confirmation, an automatic fire alarm and a fault signal to the appropriate alarm receiving centres (ACO). The fire alarm must be sent on the track without human intervention to the facility with continuous service. This facility has PSP forces and resources, indicated by the appropriate District (City) Commander, where a fire alarm receiving station (SOAP) is also installed. Damage signals are automatically directed to the fault signal receiving station of the fire monitoring system operator $[8,12,15]$.

Pursuant to Annex 1 to Regulation (EU) No 305/2011 of the European Parliament and of the Council of 9 March 2011, the construction works as a whole and their individual parts must be suitable for their intended use. In particular, the health and safety of persons in contact with them throughout the entire life cycle of these facilities should be taken into account, including fire safety conditions. According to Annex 4, permanent fire-fighting devices (SUG) and detection products and fire signalling were qualified to the group with code 10 and were considered construction products, due to their functions, important from the safety point of view - Fig. 3, 4 [3,7,12,15,17]. 


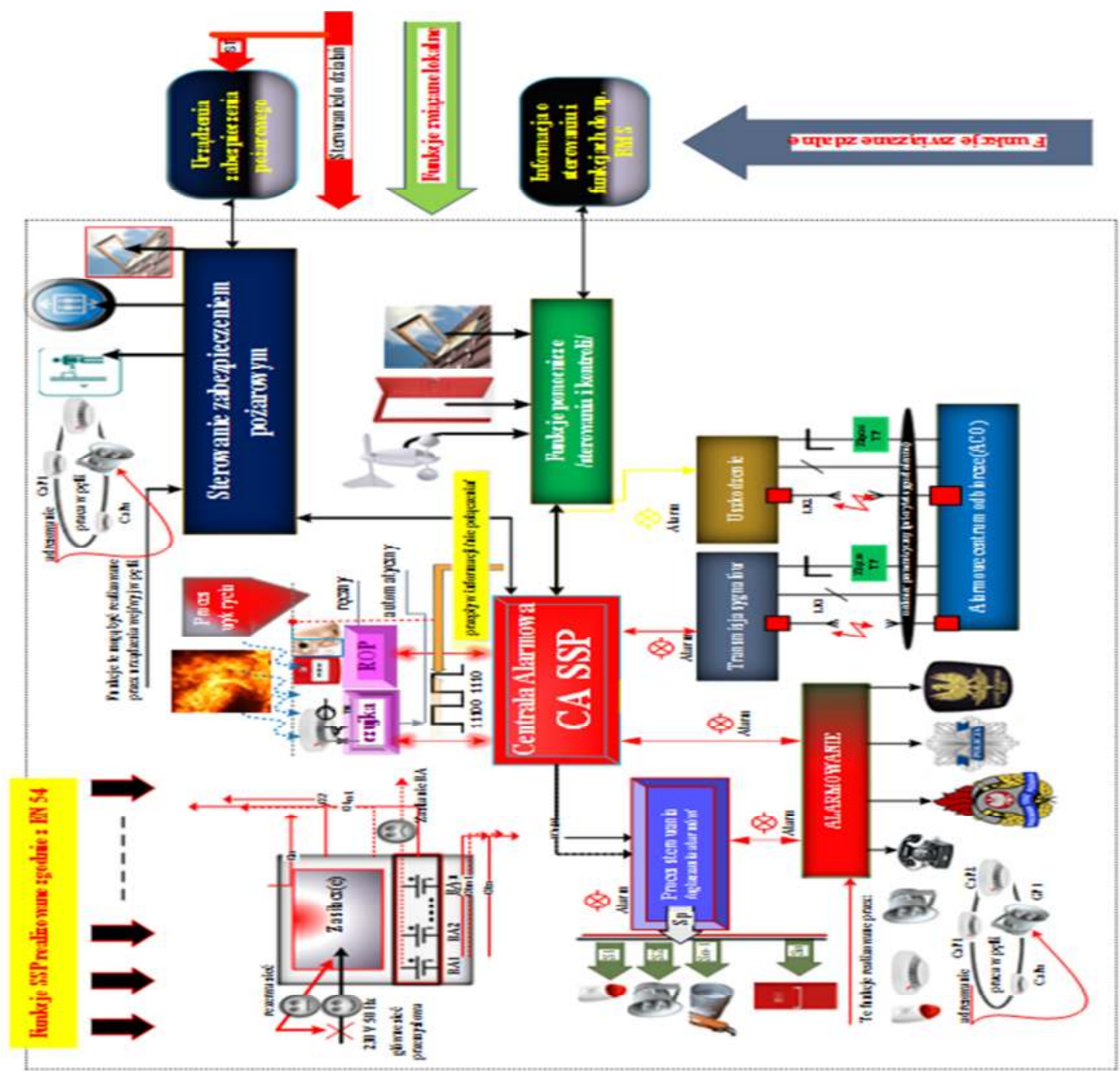

2. Construction of the fire alarm system - basic functions implemented in accordance with EN 54, where: BA - accumulator batteries, LK1,2 - telecommunication lines 1,2

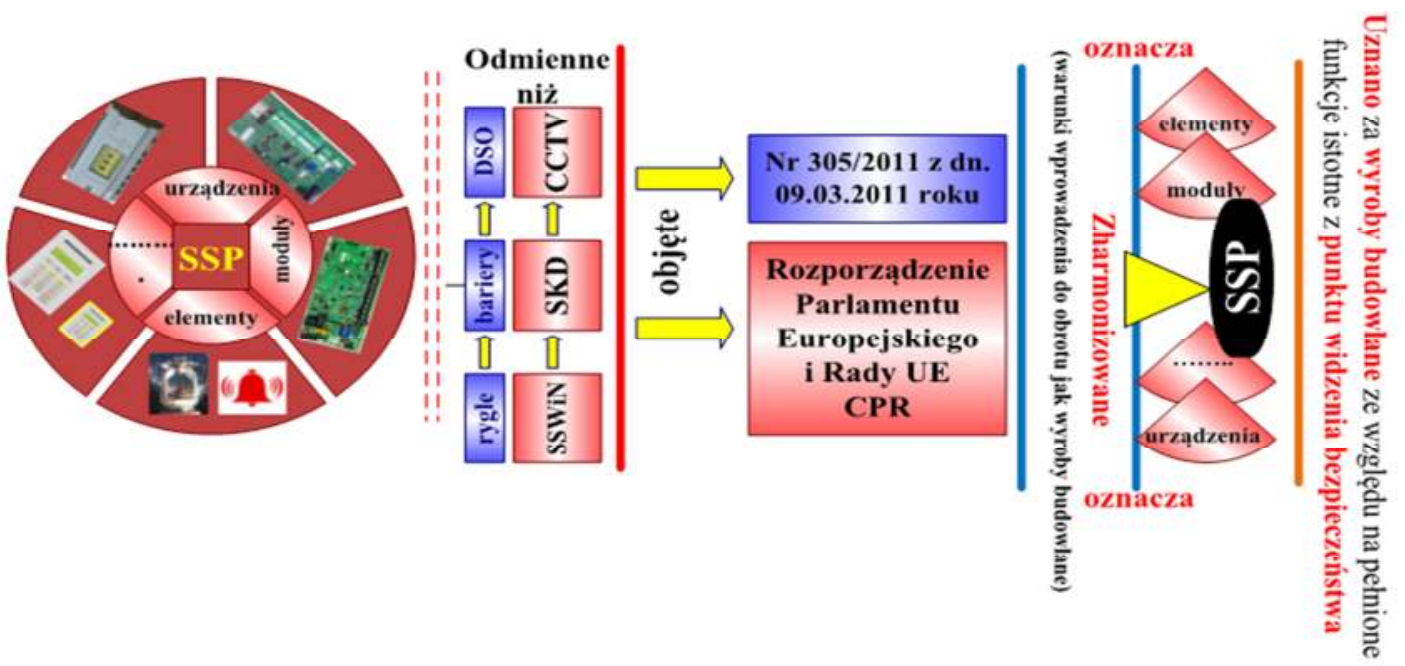

3. Fire alarm system in accordance with Annex 1 to Regulation (EU) No 305/2011 of the European Parliament and of the Council of 9 March 2011 


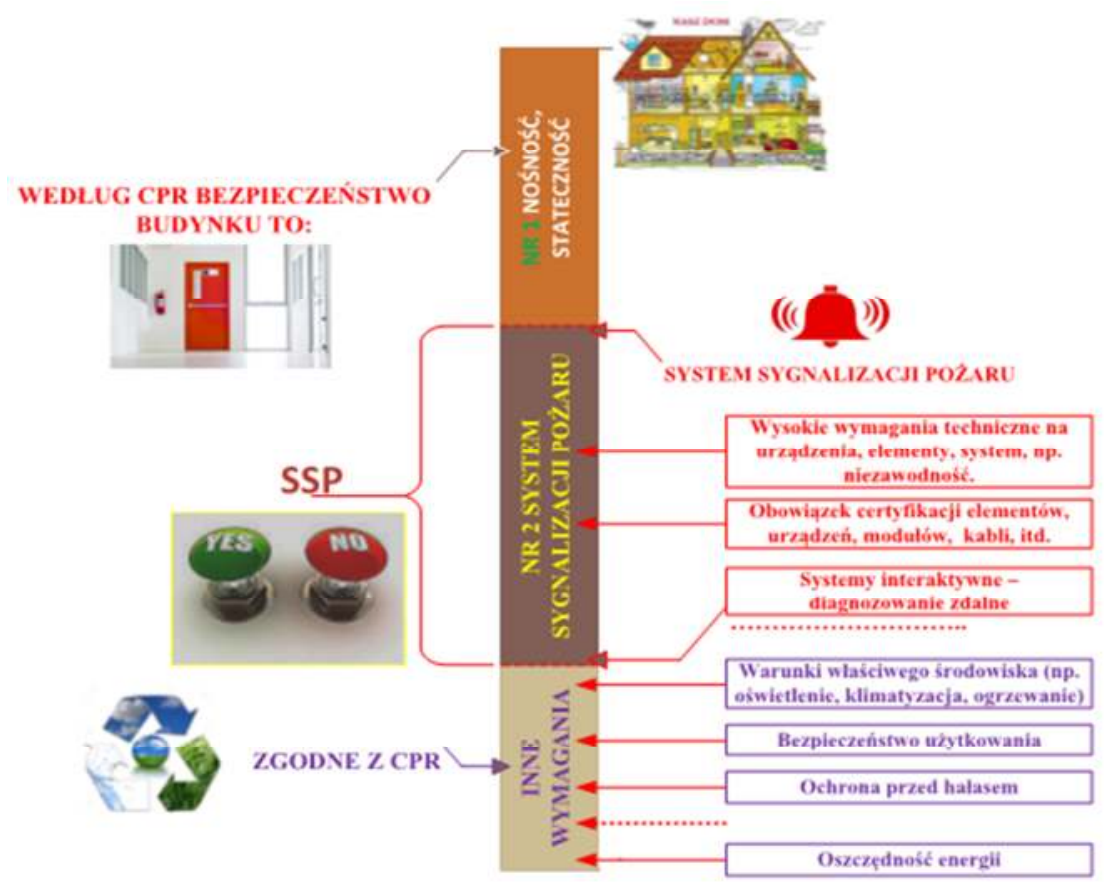

4. The fire alarm system according to EU Regulation - CPR No. 305/2011 of March 9, 2011 on construction works

\section{Focused and dispersed electronic security systems used in railway areas}

All electronic security systems can be divided according to the way of connecting elements into focused, distributed and mixed.

In the case of focused ESBs, all system components are connected to the alarm control panel by means of a line, loop or detection bus - Fig. $\mathbf{5}$.

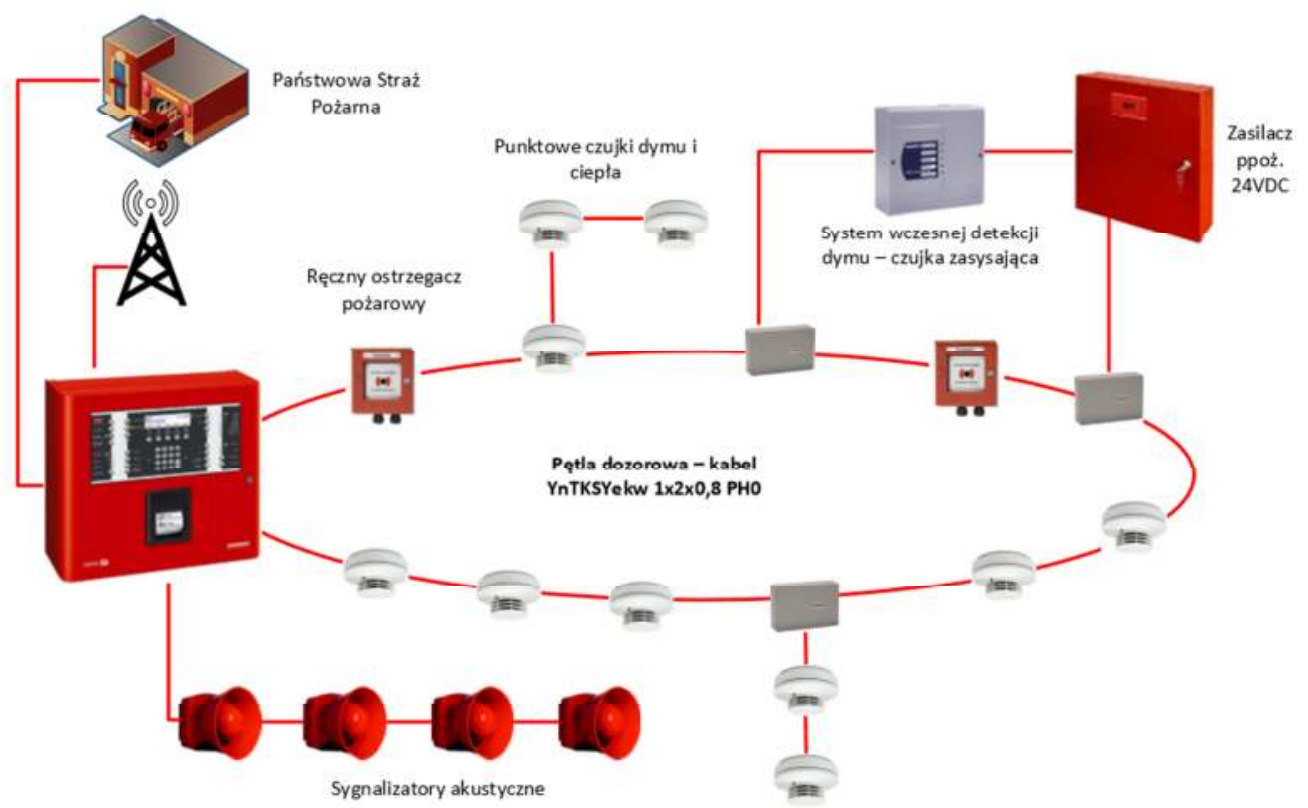

5. Diagram of a focused - simple fire alarm system

The SSP in Fig. 6 has a decentralized management, programming and operating structure. It is made of individual modules - fire alarm control panels, detection loops and is designed and programmed according to the requirements of a specific fire alarm system (ISP). In order to 
ensure the highest level of security of the fire alarm system, fire alarm control panels are most often used, which have hardware and software redundancy of all cards (i.e. duplication of all systems with the possibility of switching during a failure).

In the event of system failure, the primary system will be switched to a backup system that performs all functions of the primary system (100\% redundancy). In each case of the fire alarm control panel, there are therefore two equivalent microprocessor systems, one of which has a leading role, and the other is a backup system working in hot reserve mode. SSP also has an emergency power supply, which is most often made based on accumulator batteries having a specific capacity determined based on the energy balance.

By extracting burglary and assault signalling systems from transport supervision systems as the most common safeguards in the railway area, they can be divided into the dispersed version as follows:

a. with one transmission bus and modules;

b. with many transmission buses and modules - Fig. 7 system with one transmission bus and modules with the RS-232C interface);

c. with multiple centralized alarm control panels connected to the transmission bus;

d. using transmission line separators.

From the division of the distributed SSWiN systems to be implemented, a structure with specific quality and reliability of operation should be selected, taking into account the impact of interference from a wide range of frequencies. Fig. 7 shows a block diagram of a transport distributed system, where the control panel and individual modules are connected by a transmission bus with an RS-232C interface.

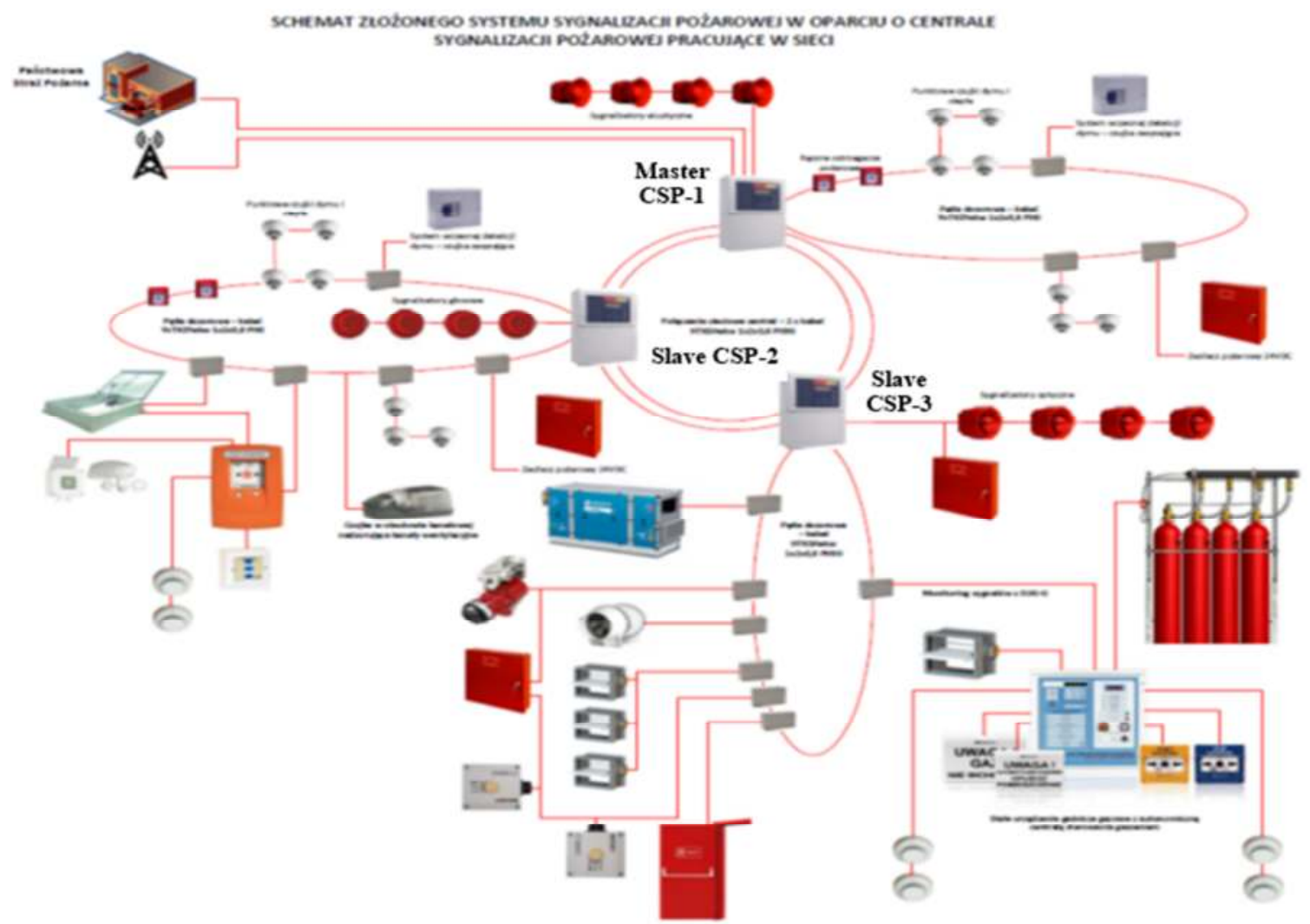

6. Diagram of a distributed fire alarm system with fire alarm control panels - CSP - 1 Master, CSP - 3 Slave, CSP - 2 Slave 


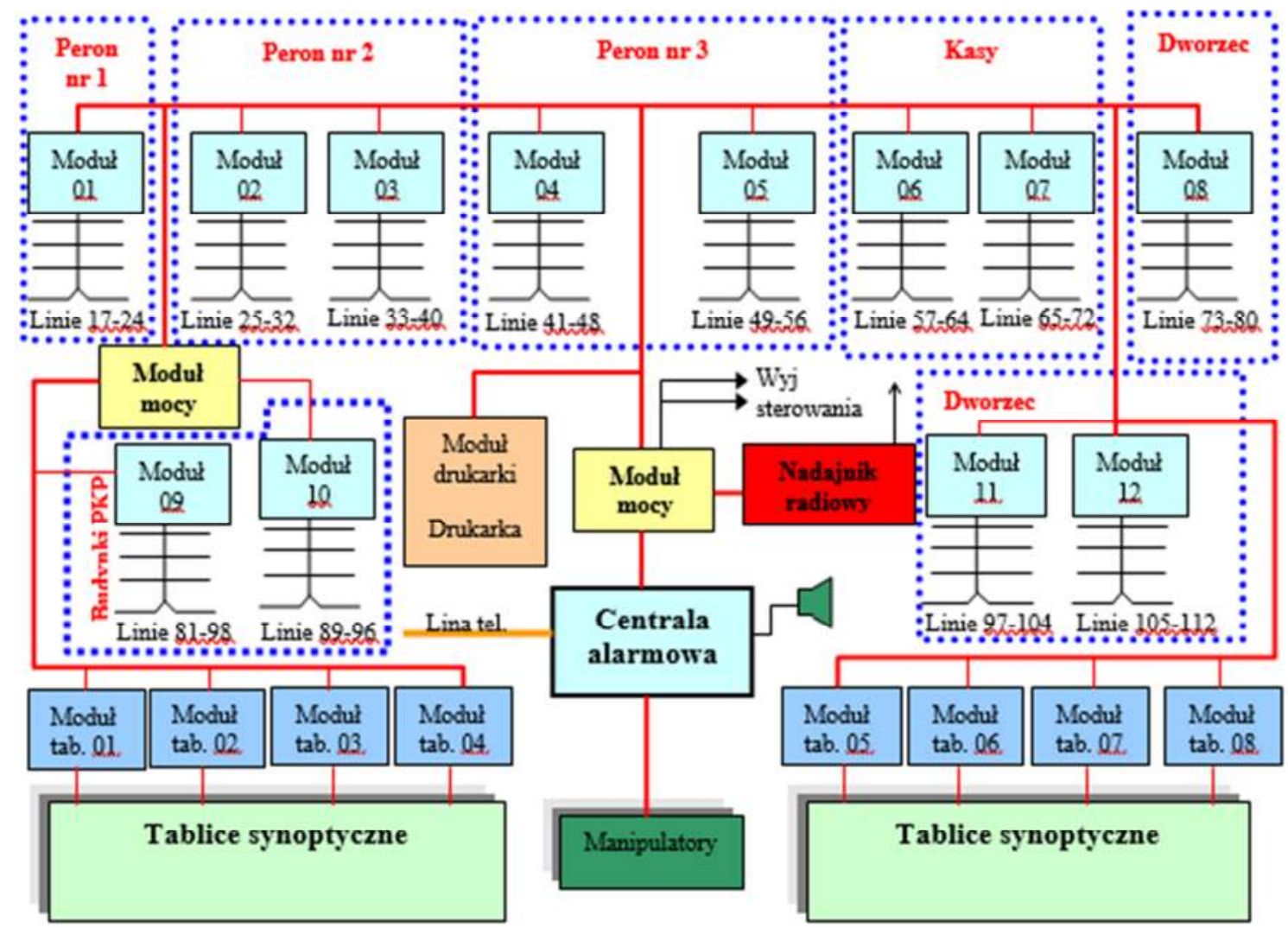

7. Block diagram of Intrusion Alarm Systems and Distributed Assault with one transmission bus and modules with RS-232C interface

This system - Fig. 7 has a modular structure with the following configuration options:

- modules extending the system to a maximum number of 128 detection lines;

- the module can be connected to a maximum of 8 detection lines simultaneously;

- power modules are used for current amplification of the entire system - their location depends on the length of the transmission bus between individual elements of the system;

- manipulators and synoptic tables depend on the needs of the protected railway facility.

All modules with the central unit are connected via one transmission bus with the RS-232C interface.

\section{Conclusions}

Electronic safety systems installed in a large railway area are operated in different climatic conditions and in the different electromagnetic environment surrounding them. Nowadays, the electromagnetic environment is shaped by countless sources that produce intentional or unintended radiation in a very wide frequency range. In the railway area, electrical systems (power supply: station, electric traction) and electronic systems (railway traffic control systems, supervision systems) coexist, which during normal operation may interfere with each other through the electromagnetic field generated. Operational tests of electronic safety systems that are installed in railway areas are the basis for improving the design of these systems and their production process. Obtaining reliable operational information is necessary for the process of controlling operation and was used to ensure the proper organization of service and repair facilities, taking into account the electromagnetic environment existing in 
the extensive railway area $[13,14,18,19,20]$. The operation of electronic security systems has the following features:

- technical devices are very complex;

- they have a high degree of automation and the use of technologically advanced digital and analogue systems (microprocessors, signal processing systems, electronic systems specialized in detectors, alarm control panels)).

The electronic safety systems use mechanical systems (e.g. electro-locks, electric locks), hydraulic systems (e.g. fire door closing, ventilator flap opening, activation of water sprinklers), optical systems (mirror systems for optical smoke detectors, infrared motion detection) ), electrical and electronic systems. The systems must have a high degree of technical readiness both while waiting for the tasks to be completed and during their implementation (work in the state of supervision and alarm). If we consider the operation of electronic security systems, this system should have the following properties:

- function properly throughout the entire time period that is necessary to perform tasks related to the transport of persons and cargo (at the railway station the system additionally ensures the safety of travellers and protects the property of significant value) $[4,5,10,15]$;

- to signal the case of damage to the supervision system by the continuous diagnosis of the technical condition $[6,9,12,18,20]$;

- stand out due to high serviceability, i.e. a defective element (detector, module) should be indicated in the control panel (e.g. addressable detectors), and the defective element should be replaced quickly and without problems with a functional one without unduly limiting the implementation of the assumed security level at the station rail;

- have high durability, do not require long-term, frequent and complicated prevention when carrying out maintenance tasks;

- be characterized by great simplicity of use for properly prepared personnel located in the alarm reception centre (this is ensured in the surveillance system by implementing specialized software ensuring full access to all functions performed by the system administrator mode).

\section{Source materials}

[1] Dyduch J., Paś J., Rosiński A.: Podstawy eksploatacji transportowych systemów elektronicznych. Wydawnictwo Politechniki Radomskiej, Radom 2011.

[2] Klimczak T., Paś J.: Analysis of reliability structures for fire signaling systems in the field of fire safety and hardware requirements, Journal of KONBIN, ISSN 1895-8281 2018, tom 46, DOI 10.2478/jok-2018-0030, pp. 191-214.

[3] Klimczak T., Paś J.: Electromagnetic environment on extensive Logistic areas and the proces of using electronic safety system, pp. 135-146, Politechnika Warszawska, Prace Naukowe Transport zeszyt 121, ISSN 1230-9265, Warszawa 2018.

[4] Kołowrocki K., Soszyńska-Budny J.: Reliability and safety of complex technical systems and processes. Springer, London 2011.

[5] Laskowski, D., Łubkowski, P., Pawlak, E., Stańczyk, P.: Anthropotechnical systems reliability. In: the monograph „Safety and Reliability: Methodology and Applications Proceedings of the European Safety and Reliability Conference ESREL 2014", editors: Nowakowski T., Młyńczak M., Jodejko-Pietruczuk A. \&Werbińska-Wojciechowska S. CRC Press/Balkema, London, 2015, pp. 399-407.

[6] Lewiński A., Perzyński T., Toruń A.: The analysis of open transmission standards in railway control and management, In Communications in Computer and Information Science, vol. 329, Berlin Heidelberg, Germany: Springer-Verlag, 2012, str. 10-17 
[7] Paś J.: Eksploatacja elektronicznych systemów transportowych. Uniwersytet Technologiczno - Humanistyczny, Radom 2015.

[8] Paś J., Dąbrowski T., Wiśnios M.: Teaching methodology of the diagnosing process on the example of the fire alarm system, DOI 10.1515jok-2017-0014, Journal of KONBiN 41(2017), s. 277-308.

[9] Paś J., Rosiński A.: Selected issues regarding the reliability-operational assessment of electronic transport systems with regard to electromagnetic interference, Eksploatacja $\mathrm{i}$ Niezawodność - Maintenance and Reliability, Vol.19, No. 3, 2017 I, s. 375-381, http://dx.doi.org/10.17531/ein.2017.3.8.

[10] Paś J., Choromański W.: Results of measurement and determination of threshold electric field component for transport security systems, Archives of Transport Systems Telematics, Volume 8, Issue 1, February 2015, s. 24-29, ISSN 1899-8208.

[11]Rosiński A.: Modelowanie procesu eksploatacji systemów telematyki transportu. Oficyna Wydawnicza Politechniki Warszawskiej, Warszawa 2015.

[12] Rozporządzenie Ministra Spraw Wewnętrznych i Administracji z dnia 7 czerwca 2010 r. w sprawie ochrony przeciwpożarowej budynków, innych obiektów budowlanych i terenów (Dz. U. Nr 109, poz. 719).

[13] Siergiejczyk M., Paś J., Rosiński A.: Train call recorder and electromagnetic interference. Diagnostyka 2015, vol. 16, no. 1, pp. 19-22.

[14] Siergiejczyk M., Paś J., Rosiński A.: Issue of reliability-exploitation evaluation of electronic transport systems used in the railway environment with consideration of electromagnetic interference, IET Intelligent Transport Systems, ISSN 1751-956X, doi: 10.1049/iet-its.2015.0183, Source: Volume 10, Issue 9, November 2016, s. 587 - 593.

[15] Sobstel J.: Monitoring pożarowy. Przepisy i wymagane dokumenty, Przegląd Pożarniczy $4 / 2012$.

[16]Żółtowski B., Niziński S.: Modelowanie procesów eksploatacji maszyn, AT-R 2002

[17] Klimczak T., Paś J.: Selected issues of the reliability and operational assessment of a fire alarm system, Eksploatacja i Niezawodnosc - Mainten ance and Reliability, Vol. 21, No. 4, 2019, pp. 553-561.

[18] Rosiński A., Paś J., Łukasiak J., Szulim M.: Exploitation of electronic systems in building objects exposed to impact of strong electromagnetic pulses", European Safety and Reliability Conference (ESREL 2019), Hannover, Germany 2019. Referat opublikowany w: „Proceedings of the 29th European Safety and Reliability Conference (ESREL)" pod redakcją Michael Beer, Enrico Zio, wydawca: Research Publishing, Singapore. str. 3320-3325, ISBN 978-981-11-2724-3.

[19]Paś J., Dyduch J.: Eksploatacja transportowych systemów nadzoru na rozległym obszarze kolejowym, Biuletyn WAT 4(660) 2010 Vol. LIX str. 197 - 208.

[20]Choromański W., Dyduch J., Paś J.: Minimizing the Impact of Electromagnetic Interference Affecting the Control System of Personal Rapid Transit in the Context of the Competitiveness of the Supply Chain, Archives Of Transport, Polish Academy of Sciences Index 201901 ISSN 0866-9546 Volume 23, Issue 2, Warsaw 2011 str. 137152. 